Original Research Paper

\title{
Kinetic Motilities of Cryopreserved Bull Spermatozoa: Owing to the Effect of Eurycoma longifolia Jack Aqueous Extract
}

\author{
${ }^{1,3}$ Falah Hasan Baiee, ${ }^{1}$ Abd Wahid Haron, ${ }^{1}$ Rosnina Haji Yusoff, \\ ${ }^{2}$ Mohamed Ariff Omar, ${ }^{1}$ Nurhusien Yimer, ${ }^{1}$ Zaid Jeber, \\ ${ }^{1}$ Salman Hammadi, ${ }^{1}$ Tarig Aldelrouf Ahmedeltayeb, ${ }^{1}$ Wan-Nor Fitri and ${ }^{4}$ Muhammad Umar \\ ${ }^{1}$ Department of Veterinary Clinical Studies, \\ ${ }^{2}$ Department of Veterinary Pre-Clinical Studies, \\ Faculty of Veterinary Medicine, Universiyi Putra Malaysia, 43400 UPM Serdang, Selangor, Malaysia \\ ${ }^{3}$ Department of Clinical Sciences, Faculty of Veterinary Medicine, University of Kufa, 54003 Najaf, Iraq \\ ${ }^{4}$ University of Agriculture, Water and Marine Sciences, Uthal, Balochistan, Pakistan
}

Article history

Received: 31-03-2017

Revised: 08-05-2017

Accepted: 29-05-2017

Corresponding Author: Abd Wahid Haron

Department of Veterinary

Clinical Studies, Faculty of

Veterinary Medicine,

Universiyi Putra Malaysia,

43400 UPM Serdang, Selangor, Malaysia

Email: wahidh@upm.edu.my, wahidharon@gmail.com

\begin{abstract}
This study was carried out to improve the kinetic motilities of frozen-thawed bull semen diluted with tris-based egg yolk diluent that was supplemented with Eurycoma longifolia jack aqueous extract. A total of 24 ejaculates were obtained from six cross-bred bulls using an electro-ejaculator. The extract of Eurycoma longifolia jack was distributed into three low doses and three high doses; cryopreserved samples were evaluated into three different times to confirm the results of kinetic motilities through different times and between groups. Path velocity (VAP $\mu \mathrm{m} / \mathrm{s}$ ), progress velocity (VSL $\mu \mathrm{m} / \mathrm{s})$, track speed (VCL $\mu \mathrm{m} / \mathrm{s})$, lateral amplitude (ALH $\mu \mathrm{m} / \mathrm{s})$, Beat Frequency (BCF Hz), straightness (STR \%), linearity (LIN \%), were evaluated three different times using Computer-assisted sperm analysis. Results revealed that the percentage of VAP, ASL and VCL were higher $(\mathrm{p}<0.05)$ in the frozen-thawed semen group supplemented with $5 \mathrm{mg} \mathrm{mL}^{-1}$ Eurycoma longifolia jack extract $(73.19 \pm 1.91,58.34 \pm 2.06$ and $117.91 \pm 2.68$ in first evaluation, then $74.22 \pm 2.06,57.45 \pm 1.72$ and $118.92 \pm 2.55$ in second evaluation and $72.95 \pm 2.27,56.75 \pm 1.30$ and $119.07 \pm 3.54$ in third evaluation; respectively). In conclusion, Eurycoma longifolia Jack aqueous extract supplementation to the semen diluent at $5 \mathrm{mg} \mathrm{mL}^{-1}$ significantly improved sperm kinetic motilities of frozen-thawed bull semen.
\end{abstract}

Keywords: Bull Semen, Kinetic Motility, Cryopreservation, Eurycoma longifolia, Tongkat Ali

\section{Introduction}

The energy and the nutrient materials which maintain mature spermatozoa are found in spermatozoon itself or in their environment. In natural breeding, the ejaculated spermatozoa obtained their feeding and energy from the secretion of female genital tract and that fluid maintain and nurse the spermatozoa until they reach the storage site (Isthmus) or fertilization site (Ampullae) of uterine tube. However, in semen that is collected in vitro using one of semen collection methods, spermatozoa utilize what they found in seminal plasma and semen diluent, but, in that case, the energy and nutrient materials are usually limited, leading to decrease the ability of sperm motility and increase the oxidative stress. Sperm motility is one of most important parameter in evaluation of the semen for natural and Artificial Insemination (AI) breeding (Correa et al., 1997; Verstegen et al., 2002). Clearly, the motility rate of frozen semen decreased owing to freezing shock (Peña et al., 2009; Yimer et al., 2015), decrease the $\mathrm{pH}$ in semen medium (Contri et al., 2013) and the oxidative stress (Ashrafi et al., 2013). Moreover, the ability of frozen semen to incubation at body temperature for long period is sharply declined as compared to fresh or chilled semen (Ahmad et al., 2015).

In fact, the evolution of Computer-Assisted Sperm Analysis (CASA) improves the confidence in the precision of semen parameters evaluation. In addition, 
CASA affords more parameters than the conventional method; for instance, path velocity, progress velocity, track speed, lateral amplitude, beat frequency, straightness, linearity, elongation and area (Joshi et al., 2003; Kumar et al., 2010). Holt and Palomo (1996) and Farrell et al. (1998) found that the estimation of sperm motility value using CASA is much precise with high repeatability than when using the subjective methods. Furthermore, sperm velocity is among the most significant values of seminal quality as a result of its correlation with sperm fertility (Verstegen et al., 2002). Thus, the aim of this study was to find out an organic, natural and that is rich in bioactive components material that could improve and maintain the kinetic motilities of frozen-thawed bull semen. Hence, the fertility rate of AI frozen-thawed straws will be improved.

Eurycoma longifolia Jack (EL) which is known locally in Malaysia as Tongkat Ali. Even so, there are various names of EL in South East Asia countries but Tongkat Ali becomes the global common name of this herbal medicinal plant. Traditionally it is used to treat fever, malaria, erectile dysfunction (Bhat and Karim, 2010). EL has been well described to be anti-oxidant (Varghese et al., 2013), anti-tumour (Al-Salahi et al., 2014; Tong et al., 2015), anti-inflammatory (Han et al., 2016), anti-malarial (Kuo et al., 2004), anti-microbial (Khanam et al., 2015), anti-parasite (Kavitha et al., 2012) and anti-stress (Talbott et al., 2013). It has also been reported to improve sex derive of the male (Ang and Sim, 1997; Low et al., 2013; Ebrahimi et al., 2016) and female (Abdulghani et al., 2012).

Eurycoma longifolia Jack contains quassinoids such as 14, 15-dihydroxy-klaineanone, eurycomanone, 13, 21dihydro-eurycomanone, $13 \alpha$ (21)-epoxy-eurycomanone, 14,15 $\beta$ dihydroxy-klaineanone, longilactone and eurycomalactone (Han et al., 2015), eurycomanol, eurycomanol-2-O- $\beta$-D-glucopyranoside (Teh et al., 2011), alkaloids, glycosides (Bhat and Karim, 2010), glycoproteins (Sambandan et al., 2006), biophenylneolignans, triterpenes, canthine-6-one and $\beta$ carboline (Guo et al., 2005).

\section{Materials and Methods}

\section{Selection of Animals}

At least four successful ejaculates were obtained from each of six bulls crossbred (Semintal-Brangus) at the farm of University Putra Malaysia (UPM); using an Electro-Ejaculator Technique (EEJ; Sarsaifi et al., 2013). Bulls were selected at age $4.80 \pm 0.59$ years old and weigh $573.33 \pm 39.78 \mathrm{~kg}$. All bulls were fed Brachiari adecumbens grass and commercial palm kernel cake at a rate of $3 \mathrm{~kg} /$ body weight. Furthermore, mineral blocks and water were provided ad libitum.
Table 1. The components of tris-based egg yolk diluent

\begin{tabular}{lll}
\hline Ingredient & $\mathrm{P}_{1}$ & $\mathrm{P}_{2}$ \\
\hline Tris $^{*}$ & $2.24 \mathrm{~g}$ & $2.24 \mathrm{~g}$ \\
Citric acid $^{*}$ & $1.48 \mathrm{~g}$ & $1.48 \mathrm{~g}$ \\
Fructose $^{*}$ & $1 \mathrm{~g}$ & $1 \mathrm{~g}$ \\
Penicillin-streptomycin $^{* *}$ & $50000 \mathrm{IU}$ & $50000 \mathrm{IU}$ \\
Egg yolk $_{\text {Glycerol }}$ & $20 \%$ & $20 \%$ \\
Distilled $_{2} \mathrm{O}$ & - & $12.8 \%$ \\
Eurycoma longifolia*** $^{* *}$ & $100 \mathrm{~mL}$ & $100 \mathrm{~mL}$ \\
\hline
\end{tabular}

(Amirat-Briand et al., 2010; Baiee et al., 2017); 'Sigma Aldrich Co. Sigma., St. Louis, MO, USA; ${ }^{* *} 15140122$, gibco ${ }^{\circledR}$ USA; ${ }^{* * *}$ Eurycoma longifolia: (TAE009110614) was provided from L Jack (M) Sdn. Bhd, 43500 Semenyih, Selangor; Malaysia

\section{Preparation of Semen Diluent}

Tris-based egg yolk diluent was prepared according to Amirat-Briand et al. (2010) and modified by Baiee et al. (2017). Briefly, the diluent was divided into two parts, (P1 and P2) (Table 1). The second part (P2) had double amount of glycerol to make the final concentration of glycerol after mixing with P1 6.4\%. Then, each part was aliquoted into seven test tubes depends on the concentration of EL extract. Moreover, semen diluent was prepared weekly and stored in $-20^{\circ} \mathrm{C}$.

\section{Semen Collection and Evaluation}

Samples of semen were collected two times a week using EEJ. Bull was prepared prior semen collection by cleaning the preputial orifice and evacuating the rectum. Later on the rectal probe was inserted with gel application on it and EEJ device was switched on and sample was collected using the collecting tube. Bulls did not treat with any sedatives or narcotic drugs. The collected ejaculates were stored at $37^{\circ} \mathrm{C}$ and taken to the Theriogenology and Cytogenetics lab of Faculty of Veterinary Medicine, UPM for evaluation. Only those with general motility $\geq 70 \%$, viability and morphology $\geq 85 \%$ and concentration $\geq 600 \times 10^{6}$ were included in the study (Baiee et al., 2017). CASA was used for the determination of semen concentration and sperm motility rate. The sperm viability and morphology were evaluates by Eosin-Nigrosin stain (EN) as described by Felipe-Pérez et al. (2008). A drop of $10 \mu \mathrm{L}$ semen was mixed with $20 \mu \mathrm{L}$ of EN stain. The mixture was smeared on glass slide and dried on a slide warmer at $45^{\circ} \mathrm{C}$. The slides were then viewed and evaluated under phasecontrast microscope at $400 \mathrm{x}$ for viability or $1000 \mathrm{x}$ for morphology. For each value 200 sperm were counted.

\section{Experimental Design}

Seven groups of tris-base egg yolk diluent have been established and EL extract was distributed in six of them at different doses; one group was without adding EL as a 
control group, three groups were low doses of EL concentrations, $\mathrm{T}_{1}=0.25 \mathrm{mg} \mathrm{mL}-1, \mathrm{~T}_{2}=0.5 \mathrm{mg} \mathrm{mL}^{-1}$ and $\mathrm{T}_{3}=1 \mathrm{mg} \mathrm{mL}^{-1}$ and three other groups were high doses of $\mathrm{EL} \mathrm{T}_{4}=2.5 \mathrm{mg} \mathrm{mL}^{-1}, \mathrm{~T}_{5}=5 \mathrm{mg} \mathrm{mL}^{-1}$ and $\mathrm{T}_{6}=$ $7.5 \mathrm{mg} \mathrm{mL} \mathrm{m}^{-1}$. The kinetic motilities for all samples was checked after 2, 7 and 14 days (d) of storage in liquid nitrogen using CASA technique.

\section{Effect of EL on Kinetic Motility of Frozen Bull Semen Quality}

For each frozen-thawed sample, six microscopic fields of both sides of CASA slide were evaluated using CASA. Path velocity (VAP $\mu \mathrm{m} / \mathrm{s}$ ), progress velocity (VSL $\mu \mathrm{m} / \mathrm{s}$ ), track speed (VCL $\mu \mathrm{m} / \mathrm{s}$; Fig. 1), lateral amplitude (ALH $\mu \mathrm{m} / \mathrm{s}$ ), beat frequency (BCF Hz; Fig. 2), straightness (STR \%), linearity (LIN \%), were recorded in all three different time evaluation for all groups.

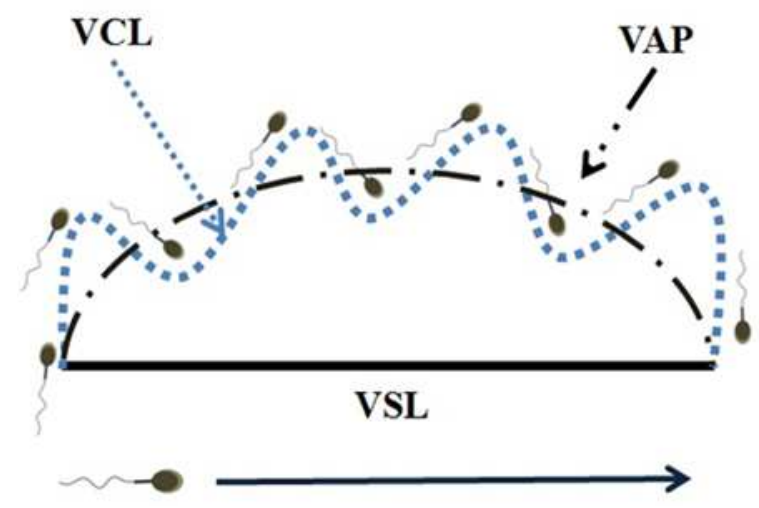

Fig. 1. Diagram shows some kinetic parameters of sperm; VCL $=$ Curvilinear velocity; VAP $=$ Average path velocity; $\mathrm{VSL}=$ Straight line velocity

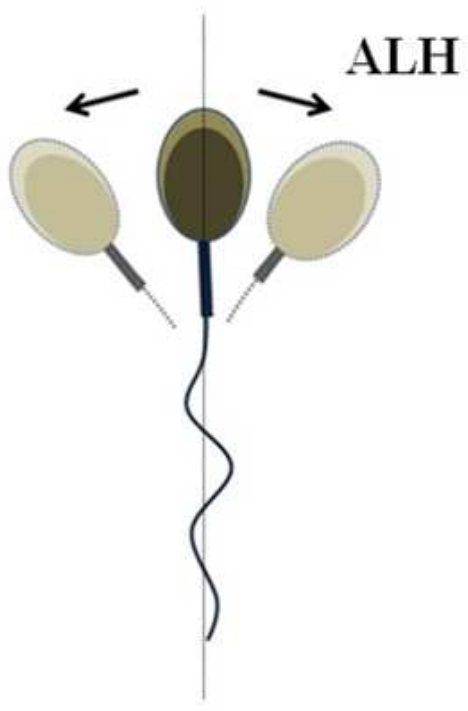

Fig. 2. Head lateral amplitude (ALH)

\section{Statistical Analysis}

SPSS program version 22 for Windows (SPSS Inc., Chicago, IL; the USA) was used for data analysis. Normality of distribution of data was checked using Shapiro-Wilk test. Differences among groups and time were determined by two-way ANOVA. Least significant Difference (LSD) test was used as a post hock test to compare the differences among groups.

\section{Results}

The outcomes of different doses of EL extract that were supplemented into tris-base egg yolk diluent on frozenthawed kinetic motility parameters in bull spermatozoa for 1st, 2nd and 3rd evaluation are summarized in Table 2-4 and Fig. 3, respectively. The percentage of VAP, VSL and VCL were higher $(p<0.05)$ in the frozen-thawed semen supplemented with $5 \mathrm{mg} \mathrm{mL}^{-1}$ EL extract $(73.19 \pm 1.91$, $58.34 \pm 2.06$ and $117.91 \pm 2.68$, in 1 st evaluation, then $74.22 \pm 2.06,57.45 \pm 1.72$ and $118.92 \pm 2.55$ in 2 nd evaluation and $72.95 \pm 2.27,56.75 \pm 1.30$ and $119.07 \pm 3.54$ in 3rd evaluation, respectively) compared to control and other groups. While the percentages of ALH, STR and LIN were not different among groups ( $\mathrm{p}>0.05)$.

In addition, adding $5 \mathrm{mg} \mathrm{mL}^{-1} \mathrm{EL}$ extract in the frozen semen diluent increased the percentage significantly of BCF (24.65 \pm 0.99 in 1st evaluation, $25.17 \pm 0.83$ in 2 nd evaluation and $24.56 \pm 1.13$ in 3 rd evaluation, respectively) compared to $\mathrm{T}_{3}, \mathrm{~T}_{6}$ and control groups (Fig. 3).

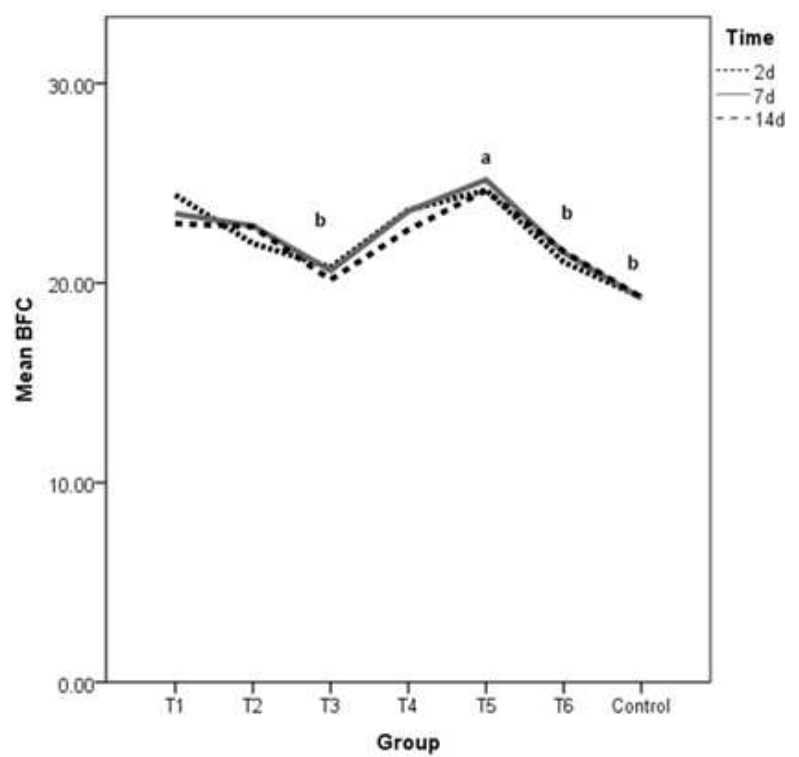

Fig. 3. Mean percentage of Beat frequency (BCF Hz) of frozenthawed bull sperm evaluated into three different times (2, 7 and $14 \mathrm{~d}$ ); Values with different superscript differ at ( $\mathrm{p}<$ 0.05 ), LSD test. $\mathrm{T}_{1}=0.25 \mathrm{mg} \mathrm{mL}^{-1}, \mathrm{~T}_{2}=0.5 \mathrm{mg} \mathrm{mL}^{-1}$, $\mathrm{T}_{3}=1 \mathrm{mg} \mathrm{mL}^{-1}, \mathrm{~T}_{4}=2.5 \mathrm{mg} \mathrm{mL}^{-1}, \mathrm{~T}_{5}=5 \mathrm{mg} \mathrm{mL}^{-1}, \mathrm{~T}_{6}$ $7.5 \mathrm{mg} \mathrm{mL}{ }^{-1}$ and Control $=0.0 \mathrm{mg} / \mathrm{mL} ; \mathrm{n}=24$ 
Table 2. Kinetic motilities of frozen bull semen using tris-based egg yolk diluent supplemented with Eurycoma longifolia extract after 2 days of cryopreservation (Mean \pm SEM)

\begin{tabular}{llllllll}
\hline 1st evaluation & $\mathrm{T}_{1}$ & $\mathrm{~T}_{2}$ & $\mathrm{~T}_{3}$ & $\mathrm{~T}_{4}$ & $\mathrm{~T}_{5}$ & $\mathrm{~T}_{6}$ & Control \\
\hline VAP $\mu \mathrm{m} / \mathrm{s}^{*}$ & $59.03 \pm 1.31^{\mathrm{b}}$ & $67.88 \pm 1.76^{\mathrm{c}}$ & $67.85 \pm 1.39^{\mathrm{c}}$ & $66.77 \pm 1.80^{\mathrm{c}}$ & $73.19 \pm 1.91^{\mathrm{a}}$ & $62.30 \pm 1.72^{\mathrm{b}}$ & $66.67 \pm 1.43^{\mathrm{c}}$ \\
$\mathrm{VSL} \mu \mathrm{m} / \mathrm{s}$ & $46.55 \pm 0.87^{\mathrm{b}}$ & $53.71 \pm 1.03^{\mathrm{c}}$ & $53.80 \pm 0.76^{\mathrm{c}}$ & $52.84 \pm 0.90^{\mathrm{c}}$ & $58.34 \pm 2.06^{\mathrm{a}}$ & $47.88 \pm 1.29^{\mathrm{b}}$ & $52.34 \pm 1.22^{\mathrm{c}}$ \\
$\mathrm{VCL} \mu \mathrm{m} / \mathrm{s}$ & $101.21 \pm 2.31^{\mathrm{c}}$ & $113 \pm 3.67^{\mathrm{ab}}$ & $110.11 \pm 2.48^{\mathrm{ab}}$ & $110.82 \pm 3.58^{\mathrm{ab}}$ & $117.91 \pm 2.68^{\mathrm{a}}$ & $104.15 \pm 2.77^{\mathrm{c}}$ & $109.06 \pm 1.73^{\mathrm{b}}$ \\
$\mathrm{ALH} \mu \mathrm{m} / \mathrm{s}$ & $6.58 \pm 0.30$ & $6.08 \pm 0.24$ & $5.84 \pm 0.12$ & $6.36 \pm 0.20$ & $6.32 \pm 0.21$ & $5.78 \pm 0.5$ & $5.85 \pm 0.25$ \\
STR \% & $78.86 \pm 1.20$ & $79.12 \pm 0.72^{\mathrm{a}}$ & $79.29 \pm 1.39^{\mathrm{a}}$ & $79.14 \pm 0.99^{\mathrm{a}}$ & $79.71 \pm 1.65^{\mathrm{a}}$ & $76.85 \pm 1.16^{\mathrm{b}}$ & $78.51 \pm 0.70$ \\
LIN \% & $45.99 \pm 0.79$ & $47.53 \pm 0.68$ & $48.86 \pm 1.13$ & $47.68 \pm 0.96$ & $49.47 \pm 1.60$ & $45.97 \pm 1.20$ & $47.99 \pm 1.11$ \\
\hline
\end{tabular}

Values within rows with different superscript differ at $(\mathrm{p}<0.05)$, LSD test; ${ }^{*}$ VAP $\mu \mathrm{m} / \mathrm{s}$ means Path velocity, VSL $\mu \mathrm{m} / \mathrm{s}$ progress velocity, VCL $\mu \mathrm{m} / \mathrm{s}$ track speed, ALH $\mu \mathrm{m} / \mathrm{s}$ lateral amplitude, BCF Hz beat frequency, STR \% straightness and LIN \% linearity. $\mathrm{T}_{1}=0.25 \mathrm{mg} \mathrm{mL}^{-1}, \mathrm{~T}_{2}=0.5 \mathrm{mg} \mathrm{mL}^{-1}, \mathrm{~T}_{3}=1 \mathrm{mg} \mathrm{mL}^{-1}, \mathrm{~T}_{4}=2.5 \mathrm{mg} \mathrm{mL}^{-1}, \mathrm{~T}_{5}=5 \mathrm{mg} \mathrm{mL}^{-1}, \mathrm{~T}_{6} 7.5 \mathrm{mg} \mathrm{mL}^{-1}$ and Control $=0.0 \mathrm{mg}$ $\mathrm{mL}^{-1} ; \mathrm{n}=24$

Table 3. Kinetic motilities of frozen bull semen using tris-based egg yolk diluent supplemented with Eurycoma longifolia extract after 7 days of cryopreservation (Mean \pm SEM)

\begin{tabular}{llllllll}
\hline 2nd evaluation & $\mathrm{T}_{1}$ & $\mathrm{~T}_{2}$ & $\mathrm{~T}_{3}$ & $\mathrm{~T}_{4}$ & $\mathrm{~T}_{5}$ & $\mathrm{~T}_{6}$ & Control \\
\hline $\mathrm{VAP} \mu \mathrm{m} / \mathrm{s}^{*}$ & $60.44 \pm 1.69^{\mathrm{b}}$ & $68.58 \pm 1.99^{\mathrm{c}}$ & $68.56 \pm 1.36^{\mathrm{c}}$ & $65.84 \pm 1.89^{\mathrm{c}}$ & $74.22 \pm 2.06^{\mathrm{a}}$ & $60.29 \pm 1.51^{\mathrm{b}}$ & $66.32 \pm 1.40^{\mathrm{c}}$ \\
$\mathrm{VSL} \mu \mathrm{m} / \mathrm{s}$ & $48.46 \pm 1.16^{\mathrm{b}}$ & $53.61 \pm 1.02^{\mathrm{c}}$ & $54.92 \pm 0.91^{\mathrm{ac}}$ & $52.64 \pm 1.07^{\mathrm{c}}$ & $57.45 \pm 1.72^{\mathrm{a}}$ & $46.88 \pm 1.89^{\mathrm{b}}$ & $52.47 \pm 1.19^{\mathrm{c}}$ \\
$\mathrm{VCL} \mu \mathrm{m} / \mathrm{s}$ & $103.17 \pm 2.61^{\mathrm{b}}$ & $112.70 \pm 3.66^{\mathrm{ab}}$ & $110.54 \pm 2.16^{\mathrm{b}}$ & $110.14 \pm 3.63^{\mathrm{b}}$ & $118.92 \pm 2.55^{\mathrm{a}}$ & $103.74 \pm 2.55^{\mathrm{b}}$ & $108.55 \pm 1.92^{\mathrm{b}}$ \\
$\mathrm{ALH} \mu \mathrm{m} / \mathrm{s}$ & $6.68 \pm 0.26$ & $6.26 \pm 0.21$ & $5.87 \pm 0.19$ & $6.44 \pm 0.13$ & $6.12 \pm 0.19$ & $6.07 \pm 0.46$ & $5.86 \pm 0.22$ \\
STR\% & $80.18 \pm 1.34^{\mathrm{a}}$ & $78.17 \pm 0.80$ & $80.11 \pm 1.16$ & $79.95 \pm 0.82$ & $77.40 \pm 1.51^{\mathrm{b}}$ & $77.75 \pm 1.36^{\mathrm{b}}$ & $79.12 \pm 0.62$ \\
LIN\% & $46.97 \pm 0.95$ & $47.57 \pm 0.66$ & $49.68 \pm 0.75$ & $47.79 \pm 0.60$ & $48.31 \pm 1.31$ & $45.18 \pm 1.01$ & $48.34 \pm 1.05$ \\
\hline
\end{tabular}

Values within rows with different superscript differ at $(\mathrm{p}<0.05)$, LSD test; ${ }^{*}$ VAP $\mu \mathrm{m} / \mathrm{s}$ means Path velocity, VSL $\mu \mathrm{m} / \mathrm{s}$ progress velocity, VCL $\mu \mathrm{m} / \mathrm{s}$ track speed, ALH $\mu \mathrm{m} / \mathrm{s}$ lateral amplitude, BCF Hz beat frequency, STR \% straightness and LIN \% linearity. $\mathrm{T}_{1}=0.25 \mathrm{mg} \mathrm{mL}^{-1}, \mathrm{~T}_{2}=0.5 \mathrm{mg} \mathrm{mL}^{-1}, \mathrm{~T}_{3}=1 \mathrm{mg} \mathrm{mL}^{-1}, \mathrm{~T}_{4}=2.5 \mathrm{mg} \mathrm{mL}^{-1}, \mathrm{~T}_{5}=5 \mathrm{mg} \mathrm{mL}^{-1}, \mathrm{~T}_{6} 7.5 \mathrm{mg} \mathrm{mL}^{-1}$ and Control $=0.0 \mathrm{mg}$ $\mathrm{mL}^{-1} ; \mathrm{n}=24$

Table 4. Kinetic motilities of frozen bull semen using tris-based egg yolk diluent supplemented with Eurycoma longifolia extract after 14 days of cryopreservation (Mean \pm SEM)

\begin{tabular}{llllllll}
\hline 3rd evaluation & $\mathrm{T}_{1}$ & $\mathrm{~T}_{2}$ & $\mathrm{~T}_{3}$ & $\mathrm{~T}_{4}$ & $\mathrm{~T}_{5}$ & $\mathrm{~T}_{6}$ & Control \\
\hline VAP $\mu \mathrm{m} / \mathrm{s}^{*}$ & $59.59 \pm 1.75^{\mathrm{c}}$ & $67.38 \pm 2.05^{\mathrm{b}}$ & $68.00 \pm 1.32^{\mathrm{b}}$ & $65.98 \pm 1.88^{\mathrm{b}}$ & $72.95 \pm 2.27^{\mathrm{a}}$ & $58.40 \pm 1.49^{\mathrm{c}}$ & $66.34 \pm 1.25^{\mathrm{b}}$ \\
VSL $\mu \mathrm{m} / \mathrm{s}$ & $47.83 \pm 1.02^{\mathrm{c}}$ & $54.38 \pm 1.49^{\mathrm{ab}}$ & $54.15 \pm 0.65^{\mathrm{ab}}$ & $53.01 \pm 1.09^{\mathrm{b}}$ & $56.75 \pm 1.30^{\mathrm{a}}$ & $45.09 \pm 1.15^{\mathrm{c}}$ & $53.11 \pm 1.06^{\mathrm{b}}$ \\
VCL $\mu \mathrm{m} / \mathrm{s}$ & $102.20 \pm 3.55^{\mathrm{b}}$ & $112.94 \pm 3.76$ & $109.90 \pm 2.22$ & $110.23 \pm 3.59$ & $119.07 \pm 3.54^{\mathrm{a}}$ & $103.07 \pm 2.43^{\mathrm{b}}$ & $108.60 \pm 1.54^{\mathrm{b}}$ \\
ALH $\mu \mathrm{m} / \mathrm{s}$ & $6.48 \pm 0.27$ & $6.19 \pm 0.17$ & $5.83 \pm 0.18$ & $6.41 \pm 0.14$ & $6.18 \pm 0.14$ & $6.02 \pm 0.30$ & $5.77 \pm 0.25$ \\
STR\% & $80.27 \pm 1.35$ & $80.71 \pm 0.67$ & $79.63 \pm 1.33$ & $80.34 \pm 0.88$ & $77.79 \pm 1.32$ & $77.21 \pm 1.43$ & $80.06 \pm 0.60$ \\
LIN\% & $46.80 \pm 1.14$ & $48.14 \pm 0.63$ & $49.27 \pm 1.00$ & $48.09 \pm 0.69$ & $47.66 \pm 1.29$ & $43.74 \pm 1.12$ & $48.90 \pm 0.91$ \\
\hline
\end{tabular}

Values within same rows with different superscript differ at $(\mathrm{p}<0.05)$, LSD test; ${ }^{*}$ VAP $\mu \mathrm{m} / \mathrm{s}$ means Path velocity, VSL $\mu \mathrm{m} / \mathrm{s}$ progress velocity, VCL $\mu \mathrm{m} / \mathrm{s}$ track speed, ALH $\mu \mathrm{m} / \mathrm{s}$ lateral amplitude, STR \% straightness and LIN \% linearity; $\mathrm{T}_{1}=0.25 \mathrm{mg} \mathrm{mL}{ }^{-1}$, $\mathrm{T}_{2}=0.5 \mathrm{mg} \mathrm{mL}^{-1}, \mathrm{~T}_{3}=1 \mathrm{mg} \mathrm{mL}^{-1}, \mathrm{~T}_{4}=2.5 \mathrm{mg} \mathrm{mL}^{-1}, \mathrm{~T}_{5}=5 \mathrm{mg} \mathrm{mL}^{-1}, \mathrm{~T}_{6} 7.5 \mathrm{mg} \mathrm{mL}^{-1}$ and Control $=0.0 \mathrm{mg} \mathrm{mL}^{-1} ; \mathrm{n}=24$

The frozen semen was evaluated into three different times after cryopreserved and stored in liquid nitrogen, so the first evaluation was done after $2 \mathrm{~d}$ of freezing, the second evaluation was done after $7 \mathrm{~d}$ of freezing and the third evaluation was done after $14 \mathrm{~d}$ of freezing. Based on the present findings, there were no differences in terms of sperm kinetic motilities among times of evaluation.

\section{Discussion}

The highest quality of semen is indicated by high sperm general motility, VAP and VSL movement of sperm cells (Lenz et al., 2011; Ibănescu et al., 2016). To the best our knowledge, this is the first study that investigated the effect of EL aqueous extract added to tris-based egg yolk diluent on sperm kinetic motilities of frozen-thawed bull semen. Based on the study findings, VAP, VSL, VCL and BCF of frozen-thawed bull semen were significantly improved at $5 \mathrm{mg} \mathrm{mL} \mathrm{mL}^{-1} \mathrm{EL}$ extract compared to the control group in all the different times of evaluation. Our findings are in line with several previous studies that have been conducted to investigate different ingredients for improving kinetic motilities. For instance, Gualtieri et al. (2014) revealed that adding 10 $\mu \mathrm{g} \mathrm{mL} \mathrm{m}^{-1}$ zinc chloride, $500 \mu \mathrm{g} \mathrm{mL}^{-1} \mathrm{D}$-aspartate and 40 $\mu \mathrm{g} \mathrm{mL} \mathrm{m}^{-1}$ coenzyme Q10 to the bull semen after thawing improved all kinetic motilities of semen as compared to the control group. El-Raey et al. (2014) found that addition of $1 \mathrm{mM}$ of melatonin for tris-based egg yolk diluent improved sperm motility, viability values and the 
fertility rate as well compared to control group in buffalo bulls. Moreover, Daramola and Adekunle (2015) found that the progressive motility of chilled buck semen were improved in extender that was supplemented with pineapple and cucumber juices compared to control group. Authors concluded that, the anti-oxidant effect of these fruit juice improved the chilled semen quality (Daramola and Adekunle, 2015). Kaka et al. (2015a) found that addition of $5 \mathrm{ng} \mathrm{mL} \mathrm{m}^{-1}$ of $\alpha$-Linolenic acid to the Bioxcell ${ }^{\circledR}$ diluent improved the VAP, VSL, VCL, STR and BCF of frozen bull semen. Moreover, they found, in another study, addition of 5 or $10 \mathrm{ng} \mathrm{mL}^{-1}$ of $\alpha$-Linolenic acid to tris-based egg yolk diluent increased the general sperm motility (Kaka et al., 2015b). Iqbal et al. (2016) found that the kinetic motilities of frozen-thawed buffalo bull semen were improved using tris-based egg yolk diluent supplemented with $2 \mathrm{mM}$ of L-cysteine when compared with other groups. The improvement of kinetic motilities in these studies was attributed to the anti-oxidant activities of their additives, by improving the membrane fluidity of sperm and resistance against freezing-thawing shock (Kaka et al., 2015b). In an earlier study that was established by Crespilho et al. (2012), it was found that lecithin based diluent did not differ much with tris-based egg yolk diluent in terms of sperm's kinetic motilities of frozen bull semen in exception of STR and LIN, the high value of these two parameters was attributed to low viscosity of lecithin based diluent as compared to other diluents such as tris-based egg yolk and skim milk diluents (Thun et al., 2002).

In bulls and other animal species, no study found in the literature assessing the impact of EL extract on frozen-thawed sperm kinetic motilities. The middle piece of spermatozoon contains mitochondria that provide the energy needed for sperm motility from inner and outer ATP store. Hence, increasing ATP in semen diluent leads to an increased in the percentage of sperm motility (Marin-Guzman et al., 2000). When mitochondria provide the spermatozoon with energy to promote its motility and other metabolic operations, the Reactive Oxygen Species (ROS) will increase as byproduct of respiration. Likewise, sperm cell membranes are rich with poly unsaturated fatty acids which are sensitive to oxidative stress owing to freezing processes. Therefore, these sites regard to be the main sites of ROS production in frozen semen. EL has antioxidant activity (Panjaitan et al., 2013; Varghese et al., 2013; Khanam et al., 2015) and Superoxide Dismutase (SOD) activity (Tambi and Imran, 2010) that can reduce the amount of ROS and protect cell membranes from the deleterious effect of ROS in frozen-thawed semen. Moreover, EL has about 70 bioactive components (Kuo et al., 2004; Bhat and Karim, 2010; Meng et al.,
2014) and also EL is well Known as energy provider (Bhat and Karim, 2010; George and Henkel, 2014) which may contribute to protect and promote sperm survival and motility by providing energy. On the other hand, we evaluated the kinetic motilities of frozenthawed semen into three different times: results showed that time of evaluation did not differ between periods of evaluation i.e., the storage semen in frozen form at $\left(-196^{\circ} \mathrm{C}\right)$ using liquid nitrogen will not change the kinetic values of sperm even stored for long period. This is in contrast with semen stored in chilled form even in different storage conditions (Bayemi et al., 2010).

\section{Conclusion}

In summary, the collected data implied that supplementation of tris-based egg yolk diluent with Eurycoma longifolia Jack (Tongkat Ali) aqueous extract at $5 \mathrm{mg} \mathrm{mL}{ }^{-1}$ improved the kinetic motilities of frozenthawed bull semen.

\section{Acknowledgement}

The authors wish to acknowledge the management and staff of University Putra Malaysia farm (TPU) and Theriogenology and Cytogenetics laboratory of the Faculty of Veterinary Medicine, UPM for their cooperation during this study. The authors also would like to thank the company L Jack $(\mathrm{M}){ }^{\circledR}$ for providing the extract of Eurycoma longifolia Jack (Tongkat Ali) with certification.

\section{Funding Information}

This research was funded by University Putra Malaysia, UPM researching grant (GPIPS/2016/9492800).

\section{Author's Contributions}

Falah Baiee, the 1st author, is the person who did the field and laboratory work and wrote the manuscript. Falah Baiee, Prof. Dr. Abd Wahid, Prof. Dr. Rosnina, Prof. Dr. Mohammed Ariff and Dr. NurHusein Yimer, participated in study conception and design, Falah Baiee, Dr. Zaid, Salman, Tarig, Fitri and Dr. Umer acquisition of data, Falah Baiee and Prof. Dr. Ariff Analysis and interpretation of data. All authors critically revised the manuscript for important intellectual content and approved the final draft to be submitted.

\section{Ethics}

The experiment was accepted by Institutional Animal Care and Use Committee. Faculty of Veterinary Medicine, UPM, (RO73/2015). 


\section{References}

Abdulghani, M., A.H. Hussin, S.A. Sulaiman and K.L. Chan, 2012. The ameliorative effects of Eurycoma longifolia Jack on testosterone-induced reproductive disorders in female rats. Reprod. Biol., 12: 247-255. DOI: $10.1016 / \mathrm{S} 1642-431 \mathrm{X}(12) 60089-8$

Ahmad, M., N. Ahmad, A. Riaz and M. Anzar, 2015. Sperm survival kinetics in different types of bull semen: Progressive motility, plasma membrane integrity, acrosomal status and reactive oxygen species generation. Reprod. Fertil. Dev., 27: 784-793. DOI: $10.1071 /$ RD13400

Al-Salahi, O.S.A., D. Ji, A.M.S.A. Majid, C. Kit-Lam and W.Z. Abdullah et al., 2014. Anti-tumor activity of Eurycoma longifolia root extracts against K-562 cell line: In vitro and in vivo study. PloS One, 9: e838180-e83818.

DOI: 10.1371/journal.pone.0083818

Amirat-Briand, L., D. Bencharif, O. Vera-Munoz, S. Pineau and C. Thorin et al., 2010. In vivo fertility of bull semen following cryopreservation with an Low Density Lipoprotein (LDL) extender: Preliminary results of artificial inseminations. Anim. Reprod. Sci., 122: 282-287.

DOI: $10.1016 /$ j.anireprosci.2010.09.006

Ang, H.H. and M.K. Sim, 1997. Effects of Eurycoma longifolia Jack on sexual behaviour of male rats. Arch. Pharmacal Res., 20: 656-658.

DOI: $10.1007 / \mathrm{BF} 02975228$

Ashrafi, I., H. Kohram and F.F. Ardabili, 2013. Antioxidative effects of melatonin on kinetics, microscopic and oxidative parameters of cryopreserved bull spermatozoa. Anim. Reprod. Sci., 139: 25-30.

DOI: $10.1016 /$ j.anireprosci.2013.03.016

Baiee, F.H., H. Wahid, Y. Rosnina, O.M. Ariff and N. Yimer et al., 2017. Hypo-osmotic swelling test modification to enhance cell membrane integrity evaluation in cryopreserved bull semen. Pertanika J. Trop. Agric. Sci., 40: 257-268.

Bayemi, P., I. Leinyuy, V. Nsongka, E. Webb and A. Ebangi, 2010. Viability of cattle sperm under different storage conditions in Cameroon. Trop. Anim. Health Product., 42: 1779-1783.

DOI: $10.1007 / \mathrm{s} 11250-010-9637-8$

Bhat, R. and A. Karim, 2010. Tongkat Ali (Eurycoma longifolia Jack): A review on its ethnobotany and pharmacological importance. Fitoterapia, 81: 669-679. DOI: 10.1016/j.fitote.2010.04.006

Contri, A., A. Gloria, D. Robbe, C. Valorz and L. Wegher et al., 2013. Kinematic study on the effect of $\mathrm{pH}$ on bull sperm function. Anim. Reprod. Sci., 136: 252-259.

DOI: $10.1016 / \mathrm{j}$.anireprosci.2012.11.008
Correa, J., M. Pace and P. Zavos, 1997. Relationships among frozen-thawed sperm characteristics assessed via the routine semen analysis, sperm functional tests and fertility of bulls in an artificial insemination program. Theriogenology, 48: 721-731. DOI: $10.1016 / \mathrm{S} 0093-691 \mathrm{X}(97) 00296-3$

Crespilho, A., M. Sá Filho, J. Dell'Aqua, M. Nichi and G. Monteiro et al., 2012. Comparison of in vitro and in vivo fertilizing potential of bovine semen frozen in egg yolk or new lecithin based extenders. Lives. Sci., 149: 1-6. DOI: 10.1016/j.livsci.2012.05.011

Daramola, J. and E. Adekunle, 2015. Preservative effects of pineapple and cucumber juices on viability of refrigerated spermatozoa of West African dwarf bucks. Pertanika J. Trop. Agric. Sci., 38: 347-360.

Ebrahimi, F., B. Ibrahim, C.H. The, V. Murugaiyah and K.L. Chan, 2016. Urinary NMR-based metabolomic analysis of rats possessing variable sperm count following orally administered Eurycoma longifolia extracts of different quassinoid levels. J. Ethnopharmacol., 182: 80-89.

DOI: $10.1016 /$ j.jep.2016.02.015

El-Raey, M., M. Badr, Z. Rawash and G. Darwish, 2014. Evidences for the role of melatonin as a protective additive during buffalo semen freezing. Am. J. Anim. Vet. Sci., 9: 252-262. DOI: 10.3844/ajavsp.2014.252.262

Farrell, P., G. Presicce, C. Brockett and R. Foote, 1998. Quantification of bull sperm characteristics measured by Computer-Assisted Sperm Analysis (CASA) and the relationship to fertility. Theriogenology, 49: 871-879. DOI: 10.1016/S0093-691X(98)00036-3

Felipe-Pérez, Y.E., M. de Lourdes Juárez-Mosqueda, E.O. Hernández-González and J. de Jesús Valencia, 2008. Viability of fresh and frozen bull sperm compared by two staining techniques. Acta Vet. Brasil., 2: 123-130.

DOI: $10.21708 / \mathrm{avb} .2008 .2 .4 .895$

George, A. and R. Henkel, 2014. Phytoandrogenic properties of Eurycoma longifolia as natural alternative to testosterone replacement therapy. Andrologia, 46: 708-721. DOI: 10.1111/and.12214

Gualtieri, R., V. Barbato, I. Fiorentino, S. Braun and D. Rizos et al., 2014. Treatment with zinc, daspartate and coenzyme Q10 protects bull sperm against damage and improves their ability to support embryo development. Theriogenology, 82: 592-598. DOI: 10.1016/j.theriogenology.2014.05.028

Guo, Z., S. Vangapandu, R. Sindelar, L. Walker and R. Sindelar, 2005. Biologically active quassinoids and their chemistry: Potential leads for drug design. Curr. Med. Chem., 12: 173-190. DOI: $10.2174 / 0929867053363351$ 
Han, Y.M., M. Jang, I.S. Kim, S.H. Kim and H.H. Yoo, 2015. Simultaneous quantitation of six major quassinoids in Tongkat Ali dietary supplements by liquid chromatography with tandem mass spectrometry. J. Separat. Sci., 38: 2260-2266. DOI: $10.1002 /$ jssc. 201500207

Han, Y.M., S.U. Woo, M.S. Choi, Y.N. Park and S.H. Kim et al., 2016. Antiinflammatory and analgesic effects of Eurycoma longifolia extracts. Arch. Pharm. Res., 39: 421-428. DOI: 10.1007/s12272-016-0711-2

Holt, W. and M. Palomo, 1996. Optimization of a continuous real-time computerized semen analysis system for ram sperm motility assessment and evaluation of four methods of semen preparation. Reprod. Fertil. Dev., 8: 219-230.

DOI: $10.1071 /$ RD9960219

Ibănescu, I., C. Leiding, Ş.G. Ciornei, P. Ro $\square$ ca and I. Sfartz et al., 2016. Differences in CASA output according to the chamber type when analyzing frozen-thawed bull sperm. Anim. Reprod. Sci., 166: 72-79. DOI: 10.1016/j.anireprosci.2016.01.005

Iqbal, S., A. Riaz, S. Andrabi, Q. Shahzad and A. Durrani et al., 2016. L-Cysteine improves antioxidant enzyme activity, post-thaw quality and fertility of Nili-Ravi buffalo (Bubalus bubalis) bull spermatozoa. Andrologia, 48: 943-949.

DOI: 10.1111 /and.12520

Joshi, A., S. Naqvi, S. Bag, A. Dang and R. Sharma et al., 2003. Sperm motion characteristics of Garole rams raised for a prolonged period in a semi-arid tropical environment. Trop. Anim. Health Produc., 35: 249-257. DOI: $10.1023 / \mathrm{A}: 1023347514476$

Kaka, A., H. Wahid, Y. Rosnina, N. Yimer and A. Khumran et al., 2015a. $\alpha$-Linolenic acid supplementation in BioXcell ${ }^{\circledR}$ extender can improve the quality of post-cooling and frozenthawed bovine sperm. Anim. Reprod. Sci., 153: 1-7. DOI: 10.1016/j.anireprosci.2014.12.001

Kaka, A., H. Wahid, Y. Rosnina, N. Yimer and A. Khumran et al., 2015b. Alpha-linolenic acid supplementation in Tris extender can improve frozen-thawed bull semen quality. Reprod. Domes. Anim., 50: 29-33. DOI: 10.1111/rda.12445

Kavitha, N., R. Noordin, K.L. Chan and S. Sasidharan, 2012. In vitro anti-toxoplasma gondii activity of root extract/fractions of Eurycoma longifolia jack. BMC Complem. Alternat. Med., 12: 91-91.

DOI: $10.1186 / 1472-6882-12-91$

Khanam, Z., C.S. Wen and I.U.H. Bhat, 2015. Phytochemical screening and antimicrobial activity of root and stem extracts of wild Eurycoma longifolia Jack (Tongkat Ali). J. King Saud Univ. Sci., 27: 23-30. DOI: 10.1016/j.jksus.2014.04.006
Kumar, D., A. Joshi and S. Naqvi, 2010. Objective assessment of sperm motion characteristics of Malpura ram lambs raised under intensive management system in semiarid tropical environment. Trop. Anim. Health Produc., 42: 653-658. DOI: 10.1007/s11250-009-9472-y

Kuo, P.C., A.G. Damu, K.H. Lee and T.S. Wu, 2004. Cytotoxic and antimalarial constituents from the roots of Eurycoma longifolia. Bioorg. Med. Chem., 12: 537-544. DOI: 10.1016/j.bmc.2003.11.017

Lenz, R., M. Kjelland, K. VonderHaar, T. Swannack and J. Moreno, 2011. A comparison of bovine seminal quality assessments using different viewing chambers with a computer-assisted semen analyzer. J. Anim. Sci., 89: 383-388.

DOI: $10.2527 /$ jas.2010-3056

Low, B.S., S.B. Choi, H.A. Wahab, P.K. Das and K.L. Chan, 2013. Eurycomanone, the major quassinoid in Eurycoma longifolia root extract increases spermatogenesis by inhibiting the activity of phosphodiesterase and aromatase in steroidogenesis. J. Ethnopharmacol., 149: 201-207. DOI: $10.1016 /$ j.jep.2013.06.023

Marin-Guzman, J., D. Mahan and R. Whitmoyer, 2000. Effect of dietary selenium and vitamin $\mathrm{E}$ on the ultrastructure and ATP concentration of boar spermatozoa and the efficacy of added sodium selenite in extended semen on sperm motility. J. Anim. Sci., 78: 1544-1550. DOI: $10.2527 / 2000.7861544 x$

Meng, D., X. Li, L. Han, L. Zhang and W. An et al., 2014. Four new quassinoids from the roots of Eurycoma longifolia Jack. Fitoterapia, 92; 105-110. DOI: 10.1016/j.fitote.2013.10.009

Panjaitan, R.G.P., E. Handharyani, Chairul and W. Manalu, 2013. Hepatoprotective activity of Eurycoma longifolia Jack. Roots. Ind. J. Tradit. Knowl., 12: 225-230.

Peña, F., R.H. Martínez, J. Tapia, C.O. Ferrusola and L.G. Fernandez et al., 2009. Mitochondria in mammalian sperm physiology and pathology: A review. Reprod. Domes. Anim., 44: 345-349. DOI: $10.1111 /$ j.1439-0531.2008.01211.x

Sambandan, T., C. Rha, A.A. Kadir, N. Aminudim and J.M. Saad, 2006. Bioactive fraction of Eurycoma longifolia: Google Patents.

Sarsaifi, K., Y. Rosnina, M. Ariff, H. Wahid and H. Hani et al., 2013. Effect of semen collection methods on the quality of pre- and post-thawed Bali Cattle (Bos javanicus) spermatozoa. Reprod. Domes. Anim., 48: 1006-1012. DOI: 10.1111/rda.12206

Talbott, S.M., J.A. Talbott, A. George and M. Pugh, 2013. Effect of Tongkat Ali on stress hormones and psychological mood state in moderately stressed subjects. J. Int. Society Sports Nutr., 10: 28-28. DOI: $10.1186 / 1550-2783-10-28$ 
Tambi, M. and M.K. Imran, 2010. Eurycoma longifolia Jack in managing idiopathic male infertility. Asian J. Androl., 12: 376-380. DOI: 10.1038/aja.2010.7

Teh, C.H., V. Murugaiyah and K.L. Chan, 2011. Developing a validated liquid chromatography-mass spectrometric method for the simultaneous analysis of five bioactive quassinoid markers for the standardization of manufactured batches of Eurycoma longifolia Jack extract as antimalarial medicaments. J. Chromatog. A, 1218: 1861-1877. DOI: $10.1016 /$ j.chroma.2011.02.014

Thun, R., M. Hurtado and F. Janett, 2002. Comparison of Biociphos-Plus ${ }^{\circledR}$ and tris-egg yolk extender for cryopreservation of bull semen. Theriogenology, 57: 1087-1094. DOI: 10.1016/S0093-691X(01)00704-X

Tong, K.L., K.L. Chan, S. AbuBakar, B.S. Low and H.Q. Ma et al., 2015. The In vitro and in vivo anticancer activities of a standardized quassinoids composition from Eurycoma longifolia on LNCaP human prostate cancer cells. PloS One, 10: e0121752-e0121752.

DOI: 10.1371/journal.pone.0121752
Varghese, C., C. Ambrose, S. Jin, Y. Lim and T. Keisaban, 2013. Antioxidant and antiinflammatory activity of Eurycoma longifolia Jack, a traditional medicinal plant in Malaysia. Int. J. Pharmaceutical Sci. Nanotechnol., 5: 1875-1878.

Verstegen, J., M. Iguer-Ouada and K. Onclin, 2002. Computer assisted semen analyzers in andrology research and veterinary practice. Theriogenology, 57: 149-179. DOI: 10.1016/S0093-691X(01)00664-1

Yimer, N., N. Muhammad, K. Sarsaifi, Y. Rosnina and H. Wahid et al., 2015. Effect of honey supplementation into Tris Extender on Cryopreservation of Bull Spermatozoa. Malaysian J. Anim. Sci., 18: 47-54. 